\title{
US health officials press Congress for Zika funds
}

\author{
Michael McCarthy \\ Seattle
}

Tom Frieden, director of the US Centers for Disease Control and Prevention, has called on Congress to move quickly to appropriate funds to support the government's response to the Zika virus disease epidemic.

Frieden, who had returned from touring the US territory of Puerto Rico, where an outbreak of Zika infections was ongoing, told reporters that funding was "crucially important and urgently needed." "The rains are coming, and with the rains will come mosquito season, and with mosquito season will be the risk of an explosive spread of Zika as well as dengue and Chikungunya."

Frieden said that evidence was "growing stronger every day" that the virus caused serious birth defects, including microcephaly. "Never before have we had a mosquito borne infection that could cause serious birth defects on a large scale. I' $m$ very concerned that before the year is out there could be hundreds of thousands of Zika infections in Puerto Rico, and thousands of infected pregnant women," Frieden said.

Director of the National Institute of Allergy and Infectious Diseases, Tony Fauci, told reporters that the lack of additional funding threatened to hobble his agency's efforts to combat the outbreak, including the development of a vaccine. Fauci said that his agency was currently coping by shifting funds from other important research programs. But he warned that there was a limit to this strategy. "There's a net sum there and you just can't make it more than it is if you don't have new resources," he said.

Since it was first identified in 1947, Zika virus disease had been largely limited to equatorial regions in Africa, southern Asia, and the Pacific Islands. However, since it was first identified in Brazil last spring, the virus has spread throughout much of South and Central America and the Caribbean. All the cases reported in the US have been from travellers who had acquired the infection abroad or from those who had sex with a traveller who returned with the infection. In Puerto Rico-where the vector for the virus, the Aedes aegypti mosquito, is common-more than 170 locally acquired cases have been reported so far this year.

President Barack Obama has requested \$1.9bn (£1.3bn; €1.7bn) in emergency funding to fight the spread of the virus. Congressional Republicans have so far have balked at appropriating the funds, and have asked for the administration to use some of the unspent $\$ 2.7 \mathrm{bn}$ appropriated by Congress to fund the US response to the Ebola virus outbreak in western Africa. Administration officials, however, have said that to do so would undermine efforts to finish its work on the Ebola outbreak, including efforts to rebuild health systems in the affected nations. 